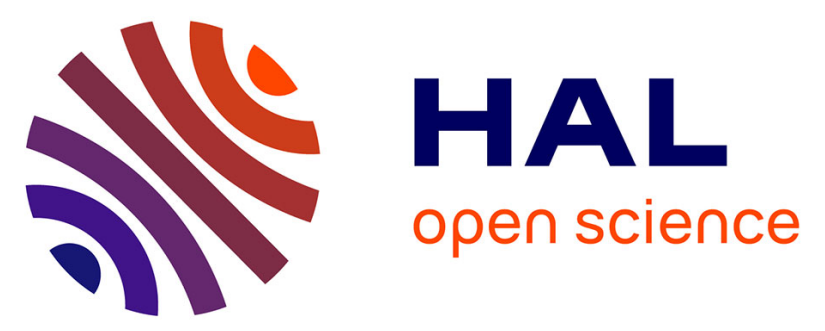

\title{
Effects of fine-scale environmental heterogeneity on local genetic structure in Macoma balthica from the Gulf of Gdañsk (southern Baltic Sea)
}

\author{
Vanessa Becquet, Rafal Lasota, Eric Pante, Adam Sokolowski, Maciej \\ Wolowicz, Pascale Garcia
}

\section{To cite this version:}

Vanessa Becquet, Rafal Lasota, Eric Pante, Adam Sokolowski, Maciej Wolowicz, et al.. Effects of fine-scale environmental heterogeneity on local genetic structure in Macoma balthica from the Gulf of Gdañsk (southern Baltic Sea). Hydrobiologia, 2013, 714 (1), pp.61-70. 10.1007/s10750-013-1530-9 . hal-00872180

\author{
HAL Id: hal-00872180 \\ https://hal.science/hal-00872180
}

Submitted on 11 Oct 2013

HAL is a multi-disciplinary open access archive for the deposit and dissemination of scientific research documents, whether they are published or not. The documents may come from teaching and research institutions in France or abroad, or from public or private research centers.
L'archive ouverte pluridisciplinaire HAL, est destinée au dépôt et à la diffusion de documents scientifiques de niveau recherche, publiés ou non, émanant des établissements d'enseignement et de recherche français ou étrangers, des laboratoires publics ou privés. 
1 Effects of fine-scale environmental heterogeneity on local genetic structure in Macoma balthica

2 from the Gulf of Gdañsk (southern Baltic Sea)

3

4 V. Becquet ${ }^{1,3}$, R. Lasota ${ }^{2,4}$, E. Pante ${ }^{1,5}$, A. Sokolowski ${ }^{2,6}$, M. Wolowicz ${ }^{2,7}$, P. Garcia ${ }^{1,8}$

5 Corresponding author: V. Becquet

$6 \quad$ Tel: 033546507637

$7 \quad$ Fax: 033546458264

$8{ }^{1}$ Littoral Environnement et Sociétés, UMR 7266 CNRS, 2 rue Olympe de Gouges, 17000 La

9 Rochelle, France

$10{ }^{2}$ Department of Marine Ecosystems Functioning, Institute of Oceanography, University of Gdañsk,

11 Al. M. Piłsudskiego 46, 81-378 Gdynia, Poland

$12 \quad 33$ E-mail: vbecquet@univ-lr.fr

13 느-mail: ocerl@ug.edu.pl

$14 \quad{ }^{5}$ E-mail: pante.eric@gmail.com

$15 \quad{ }^{6}$ E-mail: oceas@univ.gda.pl

$16 \quad{ }^{7}$ E-mail: ocemw@ug.edu.pl

$17 \quad{ }^{8}$ E-mail: pgarciam@univ-lr.fr

18 


\section{Abstract}

20 It is increasingly recognized that populations of marine organisms with potential for large-scale

21 dispersal may exhibit fine-scale genetic structure. The Gulf of Gdañsk (Poland) is an interesting

22 setting to study fine-grained population structure in marine organisms as it is characterized by chronic

23 anthropogenic pollution and strong salinity gradients. We investigated, at two nested spatial scales (35

24 and $7 \mathrm{~km}$ ), genetic structure among populations of the infaunal tellinid bivalve Macoma balthica. The

25 COI mitochondrial marker revealed a likely mix of evolutionary lineages in the Gulf, with no

26 detectable spatial structure. Seven microsatellite markers detected weak population structure,

27 separating deep and shallow populations within short distances $(7 \mathrm{~km})$ and assignment tests suggested

28 asymmetric gene flow among these populations, with no shallow recruits being detected in deep

29 waters. Given the specific environmental conditions encountered at deeper depths in the Gulf

30 (increased salinity, lower temperatures, oxygen depletion, hydrogen sulfide pollution), we suggest that

31 deeper populations may be subjected to local adaptation.

\section{Keywords}

34 Population structure ; Vistula ; Asymmetric gene flow ; Local recruitment ; Depth stratification ; 35 Microsatellites 
Many marine species are characterized by a high fecundity, large population sizes, long

39 distance dispersal via a planktonic larval stage, and, very often, low geographic differentiation. As a

40 consequence, the extent of small-scale genetic structure has long been neglected for marine organisms.

41 However, many studies have shown that marine populations may exhibit strong genetic structure due

42 to limited gene flow, genetic drift and unequal dispersion, caused by cryptic barriers or local

43 adaptation in a heterogeneous environment (Koehn et al., 1980, Mitton, 1997, Powers \& Schulte,

44 1998, Schmidt \& Rand, 2001, Riginos et al., 2002).

The Baltic Sea is a noteworthy system to study the impact of high environmental patchiness

on the genetic structure of marine organisms. It is characterized by restricted water exchanges with

47 other oceanic basins, shallow waters, and low salinities (3 to 7 PSU). Temperature and salinity are

48 strongly stratified by depth, water below 20-50 m being colder and saltier (Rheinheimer, 1995).

49 Moreover, oxygen concentration is often reduced, particularly in the bottom zone, due to an

50 eutrophication-induced increase in primary production (Cederwall \& Elmgren, 1980) and total

51 particulate matter content (Maksymowska et al., 1997) along with a high sedimentation rate (of up to

52 1-2 $\mathrm{mm} \mathrm{yr}^{-1}$; Witkowski \& Pempkowiak, 1995). In addition, the Baltic Sea suffers from chronic

53 anthropogenic pollution. Southern waters are impacted by a constant input of heavy metals from the

54 Vistula river (Gulf of Gdañsk, Sokolowski et al., 1998, 2002, 2007), which carries pollutant runoff

55 from the industrial cities of Katowice, Kracow or Warsaw (Rainbow et al., 2004, Szefer, 2002).

The infaunal bivalve, Macoma balthica is a dominant species of the benthic macrofauna in the Baltic Sea (Rumohr et al., 1996), being present from the sub-littoral to the aphotic zone (Väinölä

58 \& Varvio, 1989). Populations from the Baltic Sea are genetically distinct from those of the Atlantic

59 and the North Sea, resulting from a mixture of Atlantic and Pacific parental lineages that are

60 maintained by a strong barrier to gene flow in the Kattegat straight (Nikula et al., 2008). Local genetic

61 differentiation can be strong in this species, as evidenced by the sharp differences in allele frequencies

62 recorded along a $60 \mathrm{~m}$-long temperature gradient in the White Sea (allozymic locus Idh; Hummel et

63 al., 1998). The contrasted environmental conditions in the Gulf of Gdañsk represent an ideal place to 
study fine-scale genetic structure among $M$. balthica subpopulations. In this work, we therefore used one mitochondrial and seven microsatellite markers (Becquet et al., 2009) to determine whether local genetic structure could be detected in these southern Baltic populations. We aimed at identifying putative barriers to gene flow at two nested geographic scales: a regional one (the Gulf of Gdañsk) and a local one (along a depth gradient, away from the mouth of the Vistula River).

\section{Materials and methods}

Adult specimens of M. balthica were collected between 1997 and 1999 at 11 locations with various environmental conditions (Fig. 1 and Table 1). Puck lagoon (MW30) is characterized by strong eutrophication and anoxia. Three populations were sampled in the lee of the Hel Peninsula at 45 m (HEL45), $60 \mathrm{~m}$ (HEL60) and $85 \mathrm{~m}$ (HEL85) depth. GN40 was sampled in the main seaway between the ports of Gdynia and Gdañsk. Finally, 6 populations were sampled at the mouth of the Vistula, along a gradient of increasing depth and various pollutant concentrations (SW5 to SW60). Specimens were stored in $95 \%$ ethanol until DNA extraction. Total DNA was purified from $<15 \mathrm{mg}$ of muscle using the Dneasy ${ }^{\mathrm{TM}}$ Tissue Kit (Qiagen, Germany).

Multiple mitochondrial lineages with distinct colonization histories can co-occur in the Baltic Sea (Luttikhuisen et al., 2003; Nikula et al., 2007, 2008). If specimens from multiple lineages are indiscriminately used, an older historical signal may mask a younger and weaker geographical signal. We therefore first tested for the presence of multiple mitochondrial lineages in our collection. $313 \mathrm{bp}$ of the COI gene were successfully sequenced for 232 individuals, as in Becquet et al. (2012). In addition to the mitochondrial data, seven microsatellite loci (Mb-mac4, Mb-mac19, Mb-mac10,

$85 \mathrm{Mb}-\mathrm{mac} 17, \mathrm{Mb}-\mathrm{mac40}, \mathrm{Mb}-\mathrm{mac} 84$ and Mb-mac64) were genotyped for 165 individuals, according to 86 Becquet et al. (2009). We have attempted to genotype all individuals for which a COI sequence was 87 obtained. All individuals for whom more than 3 microsatellite loci failed to amplify were removed 88 from the analysis (Table S1). 
91 algorithm (Cassens et al., 2003). Pairwise linkage disequilibrium between microsatellite loci was

92 tested using GENEPOP version 4.0.10 (Rousset, 2008), and the significance of each test was

93 evaluated using a Markov-chain randomization procedure (MCMC) with 1000 dememorization steps,

94100 batches and 1000 iterations per batch. The numbers of alleles per population and locus $\left(\mathrm{N}_{\mathrm{all}}\right)$, and

95 the observed $\left(\mathrm{H}_{\mathrm{o}}\right)$ and expected $\left(\mathrm{H}_{\mathrm{e}}\right)$ heterozygoties under Hardy-Weinberg equilibrium were

96 calculated using Genetix 4.05.2. (Belkhir et al., 1996-2004). Allelic richness $\left(\mathrm{R}_{\text {all }}\right)$ was computed

97 using FSTAT 2.9.3.2 (Goudet, 2002) to account for differences in sampling sizes across populations.

98 Fixation indices $\left(F_{\mathrm{IS}}, F_{\mathrm{IT}}, F_{\mathrm{ST}}\right)$ were calculated using Genetix 4.05.2 according to Weir \& Cockerham

99 (1984). The significance of pairwise population differentiation, as measured by $F_{\mathrm{ST}}$, was estimated

100 based on 1000 permutations. Population self-assignment tests were conducted using Geneclass v2.0

101 (Piry et al., 2004), based on the Bayesian method of Rannala \& Mountain (1997), and incorporating

102 the exclusion-simulation significance test of Cornuet et al. (1999). The level of statistical significance

103 was set to $\alpha=0.05$.

104 Spatial population structure was further explored using bayesian clustering analyses.

105 These analyses were performed using the BYM admixture model implemented in TESS v.2.3 (Durand

106 et al., 2009), using 12,000 MCMC steps and a burnin period of 2,000 steps. Based on the results of

107 preliminary test runs, the presence of two to 4 genetic clusters was evaluated, with 10 replicate runs of

108 each Kmax (spatial interaction parameter set to 0.6, linear degree of trend). The most likely Kmax was

109 selected based on the Deviance Information Criterion (DIC), by minimizing its value and its variance,

110 and by examining plots of individual membership probabilities. The most likely run among 10

111 replicates was then selected based on DIC.

\section{Results}

114 A total of 32 COI haplotypes were detected among 232 individuals, 6 of which being putatively

115 endemic to the Baltic Sea. Three closely-related clades were observed: clade 3, clade 4 and clade 8 , 116 separated by 1 to 3 mutations along the 313 bp examined (Fig. 1 and Fig. 2). clade 4, characterized by

11712 haplotypes, was the most prevalent group, with 123 individuals. clade 3 (12 haplotypes) and clade 
1188 (6 haplotypes) group 35 and 70 individuals, respectively. There was no spatial or bathymetric trend

119 in the distribution of haplotypes (Fig. 1 and Fig. 2).

120 A multilocus nuclear genotype was obtained for 165 individuals collected at 11 sampling sites with 121 seven microsatellite markers. No linkage disequilibrium was detected $(p \geq 0.2)$. Overall, the number of 122 alleles $\left(\mathrm{N}_{\text {all }}\right)$ ranged from 2.5 (SW40) to 6.8 (HEL60 and MW30) with a total of 11.2 over the whole 123 dataset (Table 2). There was little variation in allele number between populations (mean $=5.1 \pm 1.7$ ), 124 as confirmed by the allelic richness analysis $\left(\mathrm{R}_{\text {all }}\right)$; $\mathrm{R}_{\text {all }}$ varied from 1.5 (SW40) to 1.6 (HEL45) even in 125 the population with small number of individuals (HEL85, SW40, SW60, mean value $=1.6 \pm 0.03$ ). 126 The observed heterozygosity $\left(\mathrm{H}_{\mathrm{o}}\right)$ varied from 0.3 (SW5) to 0.5 (SW30) and the mean value obtained 127 for the 11 populations was 0.4 (standard error $=0.1$ ). The expected heterozygosity $\left(H_{e}\right)$ showed little 128 variation across the whole dataset (mean and standard deviation across the 11 populations equals $1290.538 \pm 0.048$ ) and the heterozygote deficiency was quite high for all populations (mean $F_{\text {IS }}$ value and 130 standard deviation equals $0.334 \pm 0.135)$.

At the regional scale, the overall structure observed $\left(F_{\mathrm{IT}}=0.557\right)$ was essentially due to

132 the high heterozygote deficiency within populations $\left(F_{\text {IS }}=0.554\right)$ as genetic differentiation between 133 populations was quite low $\left(F_{\mathrm{ST}}=0.007, \mathrm{p}=0.27\right)$. Pairwise differentiation between populations was 134 globally non significant (data not shown). Nevertheless, the SW60 population was significantly 135 divergent from HEL60, SW5, SW10, SW20, SW30, GN40 and MW30 $\left(0.094<F_{\mathrm{ST}}<0.186\right)$. 136 Bayesian assignment of individuals to populations highlighted a great rate of self-recruitment varying 137 from 30\% (MW30) to 87\% (SW60) with a mean value of 57\% (Fig. 3). Excluding HEL85 (50\%), the 138 self-recruitment rate was function of depth (Linear regression test between paired samples, $\mathrm{R}^{2}=0.65, \mathrm{t}$ $139=2.45, \mathrm{df}=8, \mathrm{p}=0.039$, Fig.4). This result was confirmed for the Vistula populations (SW5 to 140 SW60) for which self-recruitment rate varied from 40\% for SW5 to 87\% for SW60 (Fig. 3 and Fig. 4). 141 Furthermore, beyond $40 \mathrm{~m}$ depth, this rate was higher than $80 \%(40 \%<\mathrm{SW} 5$-SW30 $<50 \%$ and $80 \%$ $142<$ SW40-SW60 < 87\%). Thus, no individual from the shallowest sites were recruited in populations 143 located between 30 and $60 \mathrm{~m}$ depth (Fig. 3).

144 Bayesian clustering analyses suggested the presence of four clusters among 165 145 individuals examined. No spatial or bathymetric trend could be detected among these clusters. 
146 Mapping clades 3, 4 and 8 onto these clusters revealed no association between multi-locus genotypes

147 and haplotypes, suggesting strong introgression (Fig. S1).

150 Discussion

\section{1- Genetic structure at the regional scale: the Gulf of Gdañsk}

\section{$154 \quad$ 1-1 Large genetic diversity and depth stratification}

155 Populations in the Gulf of Gdañsk were characterized by a large gene diversity $\left(0.440<\mathrm{H}_{\mathrm{e}}<0.591\right)$.

156 These diversity levels were similar to that obtained by Becquet et al. (2012), who observed a mean $\mathrm{H}_{\mathrm{e}}$ 157 of 0.63 among 18 European populations sampled from France to Russia. As their European 158 counterparts, Baltic populations were heterozygote deficient $\left(F_{\mathrm{IS}}=0.55\right)$, as currently observed in 159 marine mollusks (Zouros \& Foltz, 1984). However, populations were probably not subjected to 160 inbreeding, given their high genetic diversity. In comparison with European populations (mean Rall = 161 4.39), the allelic richness in the Gulf of Gdañsk was reduced $(1.53<$ Rall $<1.62)$. This result might

162 be due to the rarefaction method used to standardize allele counts (El Mousadik \& Petit, 1996), which 163 is known to underestimate the allelic richness especially when there is a large difference in the sample 164 size among populations $(5<\mathrm{N}<30)$.

165 No genetic structure was detected among shallow-water subpopulations. In addition to tests of 166 significance on fixation statistics, TESS runs confirmed the absence of genetic structuring. This result 167 was probably linked to the ability of $M$. balthica larvae to disperse over long distances (e.g. Günther et 168 al., 1998). Private alleles were not correlated with environmental factors (salinity, pollution...), but 169 gene flow was reduced between deep (40-50 m depth) and shallow stations. This pattern, concordant 170 with previous results (Hummel et al., 2000), is probably linked to the thermo-haline stratification of 171 water masses occurring in the Gulf of Gdañsk at around 40 meters (Cyberska et al., 1998, 172 Rheinheimer, 1995, Rumhor et al., 1996). 


\section{$174 \quad$ 1-2 Strong self-recruitment}

175 The assignment probability of individuals to each population highlights a great rate of self-recruitment 176 (30 to 87\%). It is now well accepted that panmixia is not the rule in the marine environment (Swearer 177 et al., 2002, Hellberg et al., 2002). On the contrary, larvae may recruit locally, because (i) spatio178 temporals movements of water masses influence larval trajectories (Gaines et al., 2003, Siegel et al., 179 2003), (ii) survival conditions vary in space and time (Gaines \& Bertness, 1992, Morgan et al., 2000, 180 Ellien et al., 2004) and (iii) reproductive success is random (Hedgecock, 1994a, 1994b). The thermo181 halocline present in the Bay of Gdañsk might be a strong vertical barrier to larval exchange and might 182 explain the different self-recruitment rate for populations living above or below this cline. The low 183 self-recruitment rate recorded at HEL85 (50\% compared to $>70 \%$ at other deep-water locations), does 184 not contradict this hypothesis, and may be explained by the specific sea-floor morphological features 185 found near the Hel Cape. Indeed, there is a relatively steep slope descending to a depth of 50+ $\mathrm{m}$ on 186 the open-sea side of the cape (Rucinska-Zjadacz \& Rudowski, 2009). Upwelling and downwelling 187 events occur often in this region (Kowalewski \& Ostrowski, 2005) and maybe responsible for cross188 slope larval transport.

\section{2- Genetic structure at the local scale, among Vistula populations}

\section{2-1 Asymmetric gene flow}

193 Genetic connectivity among Vistula populations from different depths was asymmetric, as gene flow 194 was stronger from deep to shallow stations (Fig. 3). Even if these populations are geographically close 195 to each other (horizontal distance is about $7 \mathrm{~km}$ ), they are located along a clear environmental gradient 196 (Table 1). While shallower populations (SW5 and SW10) are directly impacted by the freshwater of 197 the Vistula River, carrying heavy metal pollution (Sokolowski et al., 1998, 2002, 2007), deeper 198 populations (> $20 \mathrm{~m}$ ) are challenged by saltier waters from the open part of the Gulf of Gdañsk and

199 impacted by the release of metallic elements from the upper sediment layer that might exert toxic 200 effects on bivalves (Janas et al., 2004, Sokolowski et al., 2007). Moreover bivalves leaving in the 
201 deeper parts of the Gulf of Gdañsk can be subjected to hypoxia or anoxia and even hydrogen sulphide

202 (Janas et al., 2004), because of the strong eutrophication occurring in this zone (Laine, 2003).

203 These heterogeneous environmental conditions might favor chaotic genetic patchiness (Johnson \&

204 Black, 1982). Indeed, we observed a greater genetic heterogeneity between close populations (e.g.

205 Vistula populations), than between more distant populations (e.g at the scale of the entire Gulf of 206 Gdañsk populations, Fig. 3). The asymmetric gene flow in the Gulf of Gdañsk might be the result of 207 natural selection impacting larval and/or recruit survival induced by environmental conditions (e.g. 208 Johnson \& Black, 1982, 1984, Watts et al., 1990, Hedgecock, 1994a, Edmands et al., 1996, David et 209 al., 1997).

210 The gene flow from deep (30 to $60 \mathrm{~m}$ ) to shallow populations is probably due to the specific water 211 mass dynamics in the Vistula Estuary. In this salt wedge estuary, a sharp boundary exists between an 212 upper layer of brackish water and an intruding wedge-shaped bottom layer of denser saltwater. Under 213 the typical circulation for such estuary, low salinity surface water moves toward the open sea (flushing 214 larvae away from the mouth of the estuary), whereas sea bottom water moves toward the land (and 215 transporting larvae from deep to shallow). Moreover, the thermo-halocline may act as a physical 216 barrier to larvae dispersal, leading to genetic differentiation at a microscale, as was already found in 217 many marine organisms (e.g. Torrents et al., 2008, Bongaerts et al., 2010, Mokhtar-Jamai et al., 2011).

218 Depth-dependent timing of gonadal development and reproductive period might also influence genetic 219 differentiation. Between 0 and $25 \mathrm{~m}$ depth, spawning is regulated by the warming of surface waters 220 following air temperatures changes (Wenne, 1985 and 1993), while at intermediate depths (25-35 m) 221 the spawning period is extended because of the longer persistence of colder water temperatures. In the 222 deeper waters $(70-75 \mathrm{~m})$, spawning is uncorrelated with surface water temperatures and often 223 depends on food availability (Wenne, 1993 after Pierścieniak et al., 2010).

\section{2-2 Are SW60 populations subjected to local adaptation?}

227 Microsatellite markers revealed a significant genetic differentiation between the deepest SW 228 population (SW60) and others (except with SW40). Moreover, the SW60 population has the highest 
229 self-recruitment rate (87\%), which further supports the idea of genetic isolation between this

230 population and shallower ones. The fact that SW60 is also characterized by a great genetic diversity

$231 \quad\left(\mathrm{H}_{\mathrm{e}}=0.52\right)$ suggests that this population is not declining, or suffering from source-sink dynamics or

232 inbreeding.

233 The challenging environmental conditions recorded at the SW60 site, associated with the high genetic

234 polymorphism and reduced connectivity observed with other sites, may promote local adaptation via

235 divergent natural selection within this population (Hasting, 1983). However, populations in this region

236 deal with many natural (salinity, temperature) and/or anthropogenic stressors (eutrophication, heavy

237 metals contamination) that may have synergistic effects on population structure. It was therefore

238 difficult to distinguish which processes are directly implicated in structuring this deep population, and

239 a more thorough sampling may address this issue in the future. Thus, given the observed variation in

240 spawning time and the existence of physical barriers to gamete and larval dispersal (limited cross

241 fertilization), SW populations may be far from panmixia.

\section{References}

246 Bandelt, H.J., Forster, P., Rohl, A., 1999. Median-joining networks for inferring intraspecific phylogenies. Molecular Biology and Evolution 16: 37-48.

248 Becquet V., Lanneluc I., Simon-Bouhet B. and Garcia P. 2009. Microsatellite markers for the Baltic clam, Macoma balthica (Linné, 1758), a key species concerned by changing southern limit, in exploited littoral ecosystems. Conservation Genetics Ressources 1: 265-267.

Becquet V., Simon-Bouhet B., Pante E., Hummel H., Garcia P. 2012. Glacial refugium versus range limit: conservation genetics of Macoma balthica, a key species in the Bay of Biscay (France). Journal of Experimental Marine Biology and Ecology 432-433: 73-82.

Belkhir K., Borsa P., Chikhi P., Raufaste N., Bonhomme F. 1996-2004. GENETIX 4.05, logiciel sous windows pour la génétique des populations. Laboratoire Génome, Populations, Interactions, CNRS UMR 5000, Universités de Montpellier II, Montpellier, France. 
Bongaerts P., Riginos C., Ridgway T., Sampayo E., van Oppen M., Englebert N., Vermeulen F., Hoegh-Guldberg O., 2010. Genetic divergence across habitats in the widespread coral Seriatopora hystrix and its associated Symbiodinium. PLoS ONE, 5, e10871.

Cassens, I., Van Waerebeek, K., Best, P.B., Crespo, E.A., Reyes, J., Milinkovitch, M.C., 2003. The phylogeography of dusky dolphins (Lagenorhynchus obscurus): a critical examination of network methods and rooting procedures. Molecular Ecology 12 : 1781-1792.

Cederwall H., Elmgren R., 1980. Biomass increase of benthic macrofauna demonstrates eutrophication in the Baltic Sea. Ophelia (Suppl. 1): 287-204.

Cornuet J.M., Piry S., Luikart G., Estoup A., Solignac M., 1999. New methods employing multilocus genotypes to select or exclude populations as origins of individuals. Genetics 153: 1989-2000.

Cyberska B., Lauer Z., Trzosinska A., 1998. Environmental conditions in the Polish zone of southern Baltic sea during 1997. Institute of Meteorology and Water Management, Marine Branch Materials, Gdynia, pp. 211-240.

David P., Perdieu M.A., Pernot A.F., Jarne P., 1997. Fine-grained spatial and temporal population genetic structure in the marine bivalve Spisula ovalis. Evolution 51: 1318-1322.

Durand, E., Jay, F., Gaggiotti, O.E., François, O., 2009. Spatial inference of admixture proportions and secondary contact zones. Molecular Biology and Evolution 26: 1963-1973.

Edmands S.P., Moberg E., Burton R.S., 1996. Allozyme and mitochondrial DNA evidence of population subdivision in the purple sea urchin Strongylocentrotus purpuratus. Marine Biology 126: 443-450.

El Mousadik, A., Petit, R.J., 1996. High level of genetic differentiation for allelic richness among populations of the argan tree (Argania spinosa (L.) Skeels) endemic to Morocco. Theorical and Applied Genetic 92: 832-839.

Ellien C., Thiebaut E., Dumas F., Salomon J.C., Nival P., 2004. A modeling study of the respective role of hydrodynamic processes and larval mortality on larval dispersal and recruitment of benthic invertebrates: example of Pectinaria koreni (Annelida: Polychaeta) in the Bay of Seine (English Channel). Journal of Plankton Research 26: 117-132. 
Gaines S.D., Bertness M.D., 1992. Dispersal of juveniles and variable recruitment in sessile marine species. Nature 360: 579-580.

Gaines S.D., Gaylord B., Largier J.L., 2003. Avoiding current oversights in marine reserve design. Ecological Applications 13: S32-S46.

Goudet J., 2002. FSTAT version 2.9.3.2. Available from Jerome.goudet@ie.zea.unil.ch, via email. Institute of Ecology, UNIL, CH-1015, Lausanne, Switzerland.

290 Günther C-P., Boysen-Ennen E., Niesel V., Hasemann C., Heuers J., Bittkau A., Fetzer I., Nacken M., Schlüter M., Jaklin S., 1998. Observations of a mass occurrence of Macoma balthica larvae in midsummer. Journal of Sea Research 40: 347-351.

Hasting A., 1983. Can spatial variation alone lead to selection for dispersal ? Theorical Population

Hedgecock D., 1994a Does variance in reproductive success limit effective population sizes of marine organisms ? Pages 122-134 in A.R. Beaumont eds. Genetics and evolution of aquatic organisms. Chapman and Hall, London, UK.

298 Hedgecock D., 1994b. Temporal and spatial genetic structure of marine anomal populations in the California Current. California Cooperative Oceanic Fisheries Investigations Reports, 35: 7381.

Hellberg, M.E., Burton, R.S., Neigel, J.E., Palumbi, S.R., 2002. Genetic assessment of connectivity among marine populations. Bulletin of Marine Science 70: 273-290.

Hummel H., Günther C-P., Bogaards R., Fedyakov V., 1998. Variation in genetic traits of the Baltic clam Macoma balthica from a tidal gradient in the subartic. Polar Biology 19: 342-347. populations of the Gulf of Gdañsk with respect to hypoxia and hydrogen sulphide. Oceanologia 46: 85-102. 
311 Johnson M.S., Black R., 1982. Chaotic patchiness in an intertidal limpet, Siphonaria sp. Marine $312 \quad$ Biology 70: 157-164.

313 Johnson M.S., Black R., 1984. Pattern beneath the chaos - the effect of recruitment on genetic 314 patchiness in an intertidal limpet. Evolution 38: 1371-1383.

315 Koehn R.K., Newell R.I., Immerman F., 1980. Maintenance of an aminopeptidase allele frequency 316 cline by natural selection. Proceedings of National Academy of Sciences USA 77: 5385-89.

317 Kowalewski M., Ostrowski M., 2005. Coastal up- and downwelling in the southern Baltic. $318 \quad$ Oceanologia 47: 453-475.

319 Laine A.O., 2003. Distribution of soft-bottom macrofauna in the deep open Baltic Sea in relation to 320 environmental variability. Estuarine, Coastal and Shelf Science 57: 87-97.

321 Luttikhuisen, P.C., Drent, J., Baker, A.J., 2003. Disjunct distribution of highly diverged mitochondrial 322

Mokhtar-Jamaï, K., Pascual, M., Ledoux, J.B., Coma, R., Féral, J.P., Garrabou, J., Aurelle, D., 2011

Mitton J.B., 1997. Selection in natural populations. Oxford University Press, New York

Morgan L.E., Wing S.R., Botsford L.W., Lundquist C.J., Diehl J.M., 2000. Spatial variability in red sea urchin (Strongylocentrotus franciscanus) recruitment in northern California. Fisheries Oceanography 9: 83-98.

Nikula, R., Strelkov, P., Väinölä, R., 2007. Diversity and trans-arctic invasion history of mitochondrial 338 lineages in the North Atlantic Macoma balthica complex (Bivalvia: Tellinidae). Evolution 61, $928-941$. 
Nikula R., Strelkov P., Väinölä R., 2008. A broad transition zone between an inner Baltic hybrid swarm and a pure North Sea subspecies of Macoma balthica (Mollusca, Bivalvia). Molecular Ecology 17: 1505-1522.

342 Pierścieniak K., Grzymała J., Wołowicz M., 2010. Differences in reproduction and condition of Macoma balthica and Mytilus trossulus in the Gulf of Gdańsk (Southern Baltic Sea) under anthropogenic influences. Oceanological and Hydrobiological Studies 4: 17-32.

Piry S., Alapetite A., Cornuet J.M., Paetkau D., Baudouin L., Estoup A., 2004. GeneClass2 : a software for genetic assignment and first-generation migrant detection. Journal of Heredity 95: $536-539$.

Powers DA., Schulte P.M., 1998. Evolutionary adaptations of gene structure and expression in natural populations in relation to a changing environment: a multidisciplinary approach to address the million-year saga of a small fish. Journal of Experimental Zoology 282: 71-94.

Rainbow P.S., Fialkowski W., Sokolowski A., Smith B.D., Wolowicz M., 2004. Geographical and seasonal variations of trace metal bioavailabilities in the Gulf of Gdańsk, poland using mussels (Mytilus trossulus) and barnacles (Balanus improvisus) as biomonitors. Marine Biology 144: 33-45.

Rannala B., Mountain J., 1997. Detecting immigration by using multilocus genotypes. Proceedings of National Academy of Sciences USA 94: 9197-9201.

Rheinheimer G., 1995. Meereskunde der Ostsee. 2nd ed. Springer verlag, Berlin.

358 Riginos C., Sukhdeo K., Cunningham CW., 2002. Evidence for selection at multiple allozyme loci across a mussel hybrid zone. Molecular Biology and Evolution 19: 347-351.

360 Rousset F., 2008. GENEPOP'007: a complete re-implementation of the genepop software for Windows and Linux. Molecular Ecology Resources 8: 103-106.

362 Rucińska-Zjadacz M., Rudowski S., 2009. Underwater slope relief of Cape Hel, Oceanological and Hydrobiological Studies 38: 111-119.

364 Rumohr H., Bonsdorff E., Pearson T.H., 1996. Zoobenthic succession in Baltic sedimentary habitats. 365 Archive of Fishery and Marine Research 44: 179-214. 
Schmidt PS., Rand DM., 2001. Adaptive maintenance of genetic polymorphism in an intertidal barnacle: habitat- and life-stage-specific survivorship of MPI genotypes. Evolution 55: 13361344.

Siegel D.A., Kinlan B.P., Gaylord B., Gaines S.D., 2003. Lagrangian descriptions of marine larval dispersion. Marine Ecology Progress Series 260: 83-96.

Sokolowski A., Wolowicz M., Hummel H., Bogaards R., 1998. Physiological responses of Macoma balthica to copper pollution in the Baltic. Oceanologica Acta 22: 431-439.

Sokolowski A., Fichet D., Garcia-Meunier P., Radenac G., Wolowicz M., Blanchard G., 2002. The relationship between metal concentrations and phenotypes in the Baltic clam Macoma balthica (L.) from the Gulf of Gdańsk, southern Baltic. Chemosphere 47: 475-484.

Sokolowski A., Wolowicz M., Hummel H., 2003. Free amino acids in the clam Macoma balthica L. (Bivalvia, Mollusca) from brackish waters of the southern Baltic Sea. Comp. Biochemistry and Physiology Part A. Molecular and Integrative Physiology 134: 579-592.

Sokolowski A., Wolowicz M., Hummel H., 2007. Metal sources to the Baltic clam Macoma balthica (mollusca: Bivalvia) in the southern Baltic Sea (the Gulf of Gdańsk). Marine Environmental Research 63: 236-256.

Swearer, S.E., Shima, J.S., Hellberg, M.E., Thorrold, S.R., Jones, G.P., Robertson, D.R., Morgan, S.G., Selkoe, K.A., Ruiz, G.M., Warner, R.R., 2002. Evidence of selfrecruitment in demersal marine populations. Bulletin of Marine Science 70: 251-271.

Szefer P. (2002) Metals, metalloids and radionuclides in the Baltic ecosystem. Elsevier, Amsterdam.

Torrents O., Tambutte' E., Caminiti N., Garrabou J., 2008. Upper thermal thresholds of shallow vs. deep populations of the precious Mediterranean red coral Corallium rubrum (L.): Assessing the potential effects of warming in the NW Mediterranean. Journal of Experimental Marine Biology and Ecology 357: 7-19.

Väinölä R., Varvio S.L., 1989. Biosystematics of Macoma balthica in northwestern Europe. in: Ryland JS, Tyler PA (eds). Reproduction, Genetics and Distribution of Marine Organisms. Proceedings of the 23rd European Marine Biology Symposium. Olsen and Olsen, Fredensborg, pp 309-317. 
394 Watts R.J., Johnson M.S., Black R., 1990. Effects of recruitment on genetic patchiness in the urchin 395 Echinometra matchaei in Western Australia. Marine Biology 105: 141-151.

396 Weir B., Cockerham C., 1984. Estimating F-statistics for the analysis of population structure. $397 \quad$ Evolution 38: 1358-1370.

398 Wenne R., 1985. Microgeographic differentiation of the reproductive cycle of Macoma balthica (L.) in the Gdañsk Bay (South Baltic), and the relationship between this cycle and energy reserve changes. - Polish Archives of Hydrobiology 32: 47-63.

401 Wenne R., 1993. Zróżnicowanie przestrzenne i ewolucja wybranych gatunków małży morskich, 402 Wydawnictwo Uniwersytetu Gdańskiego, Gdańsk,160 pp (in Polish).

403 Witkowski A., Pempkowiak J., 1995. Reconstructing the development of human impact from diatom and ${ }^{210} \mathrm{~Pb}$ sediment dating (The Gulf of Gdańsk-Southern Baltic Sea). Geogr. Polon. 64: 6376.

406 Zouros, E., Foltz, D.W., 1984. Possible explanation of heterozygote deficiency in bivalve molluscs. Malacologia 25, 583-592.

408 
1 Fig.1: Sampling locations and haplotype distribution in the Gulf of Gdañsk. HEL populations

2 were collected close to the Hel Peninsula, MW30 in the Puck lagoon, GN40 in the main

3 pathway of marine traffic and SW5 to SW60 in the Vistula mouth. Haplotype groups

4 represents the most common haplotypes and their closest relatives (see haplotype network in

5 Fig.2). Haplotypes H3 and H4 correspond to H3 and H4 of Becquet et al. 2012.

6

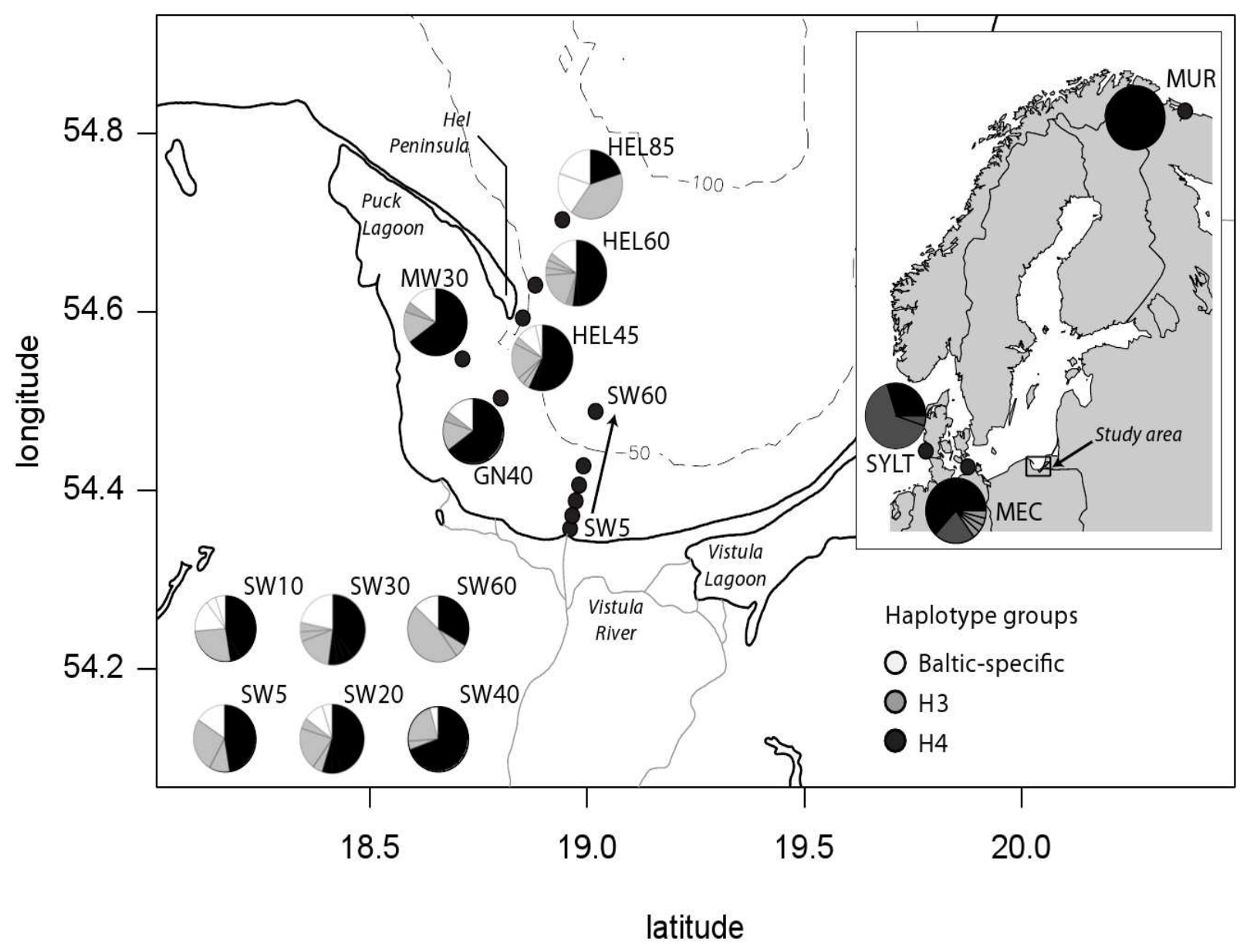


9 Fig.2: Minimum spanning network displaying mitochondrial variation along a $313 \mathrm{bp}$ of the

10 COI gene. Each circle represents a haplotype. Circle size is proportional to haplotype

11 frequency $(\mathrm{n}=30,52,106$ for $\mathrm{H} 8, \mathrm{H} 3, \mathrm{H} 4$, respectively; rares haplotypes have a frequency

12 between one and four). Each segment represents a single mutational event. H8 are 13 characteristic of Baltic.

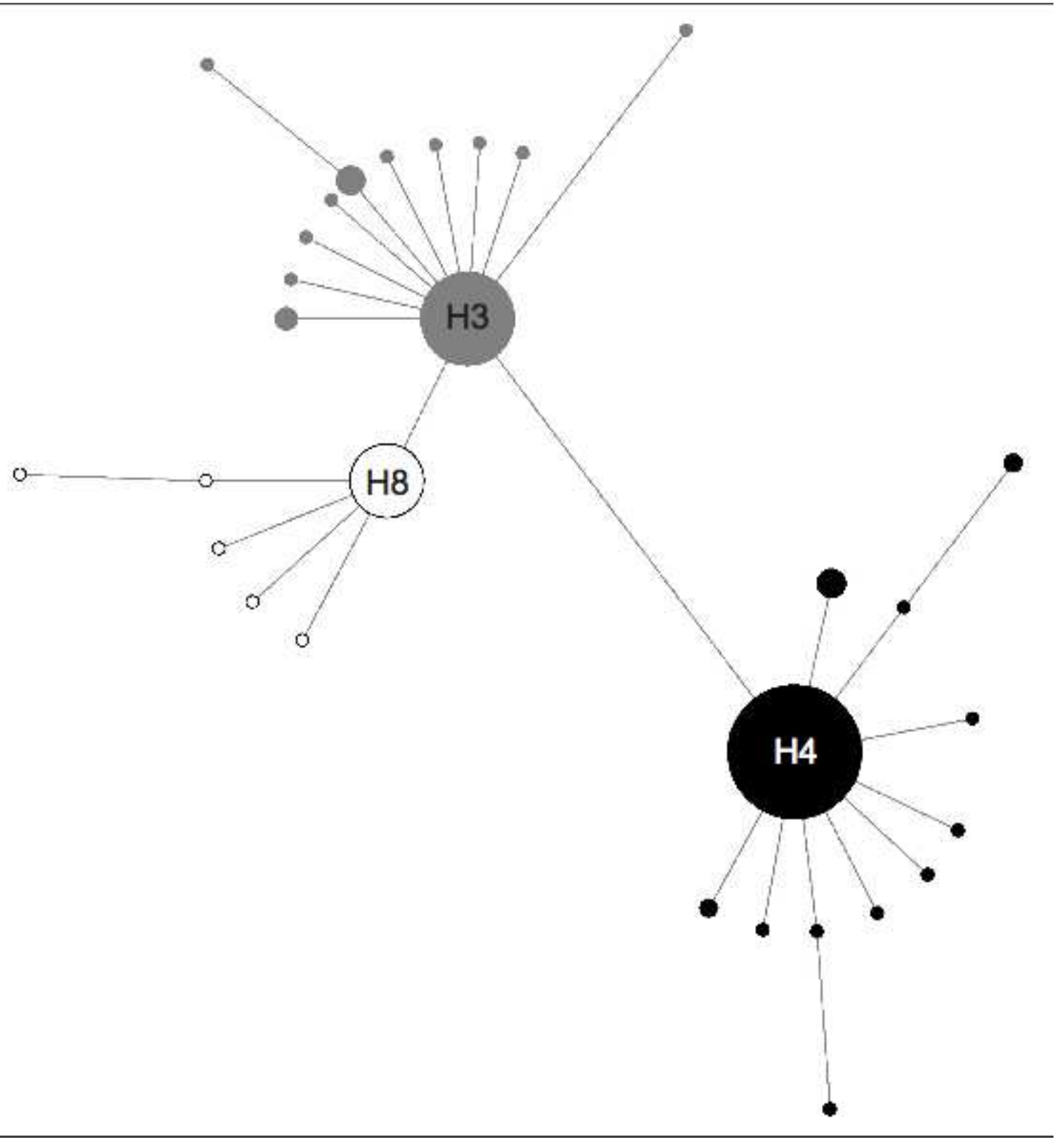


15 Fig.3: Assignment results. For each population, percentage of individuals was assigned to

16 each potential source (Larval origin) and represented by a square. Square size is a function of

17 a percentage of individuals.

18

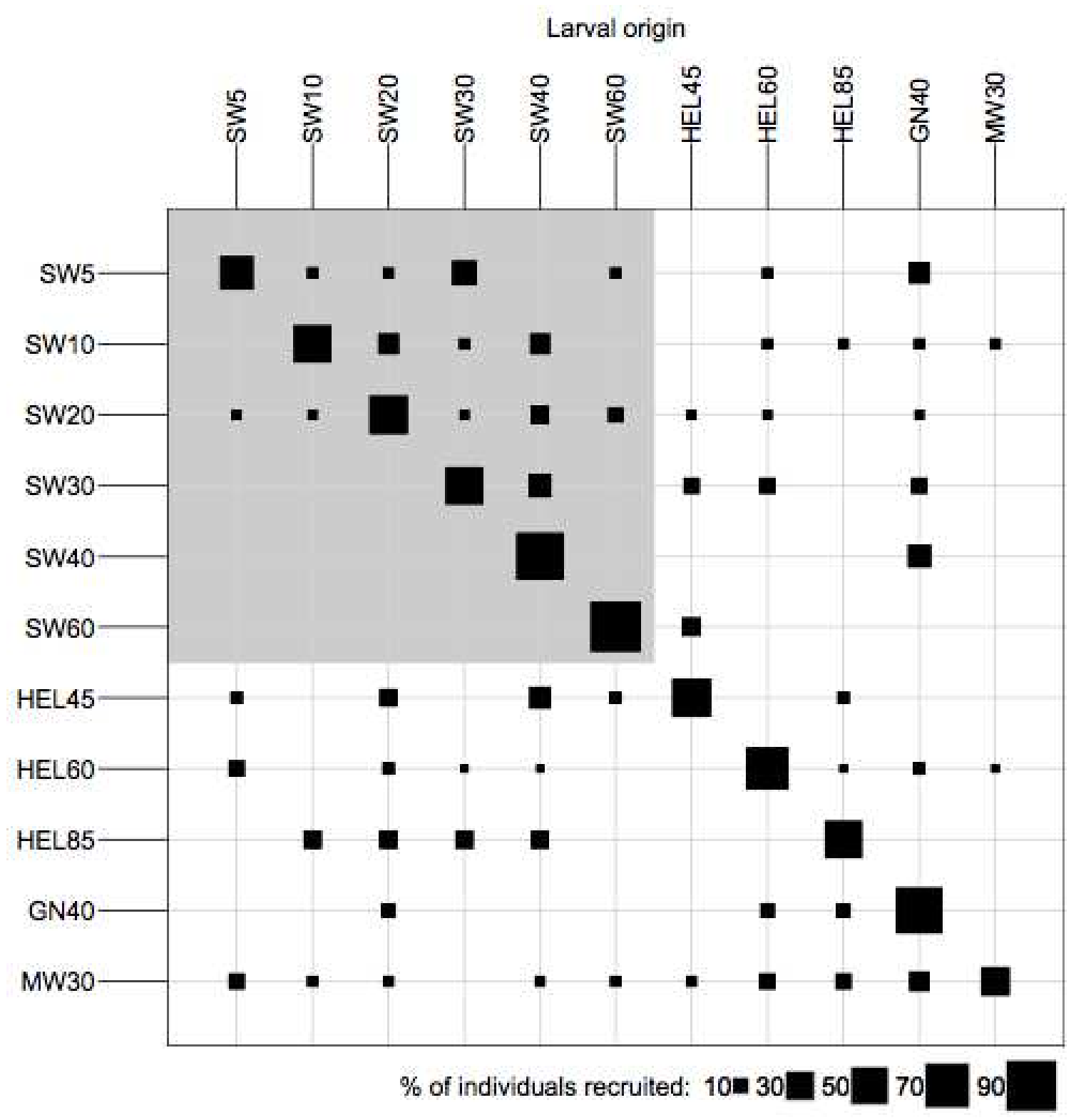


20 Fig. 4: Relationship between sampling depth and the level of self-recruitment as estimated by

21 GeneClass2. Top left corner: results of the linear regression analysis. R2 is adjusted for the

22 number of variables used in the model.

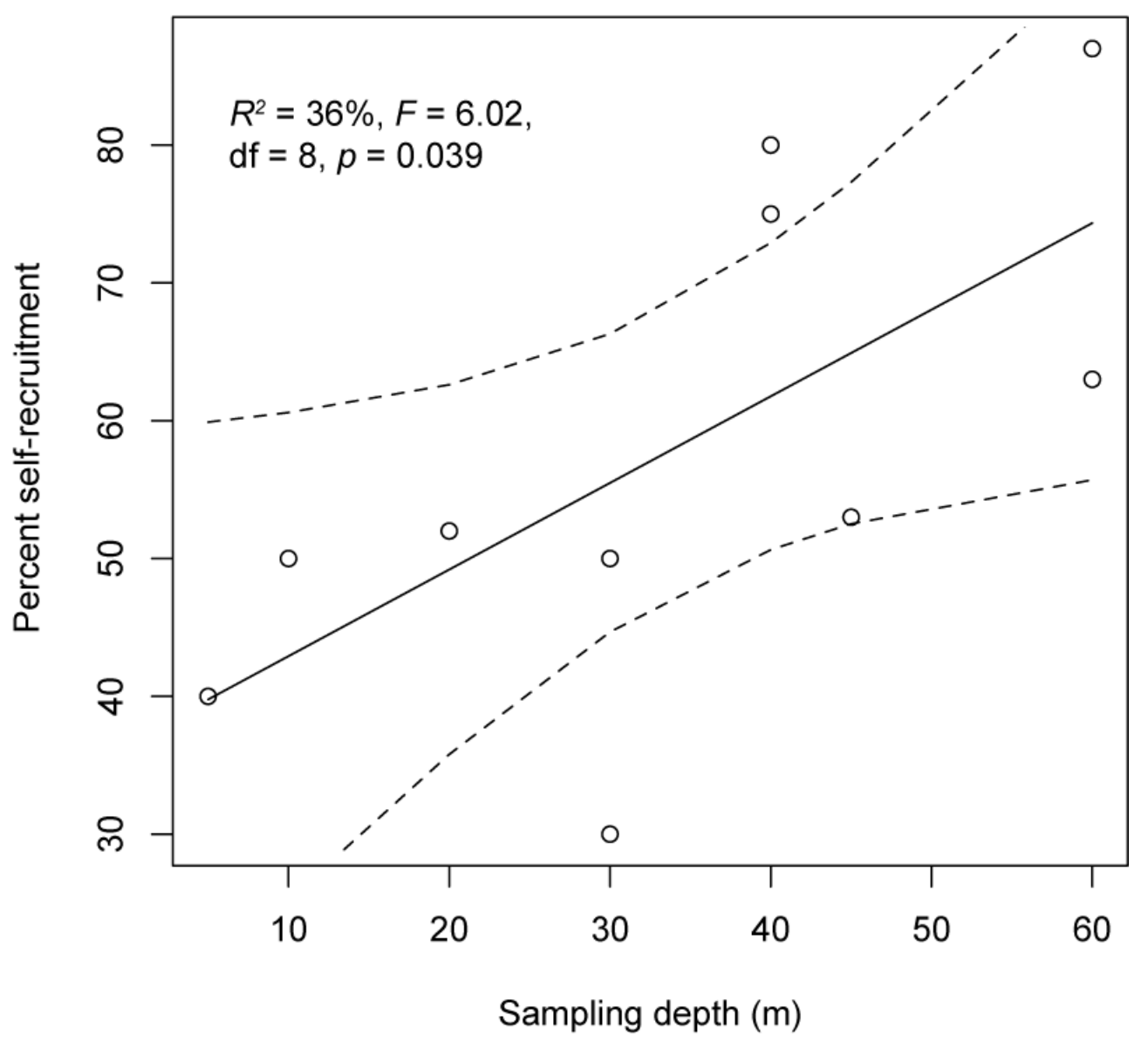

24 
1 Table 1: Physico-chemical characteristics of sampling locations in the Vistula river mouth. Data are presented as means. More detailed

2 information about metallic contamination can be found in Sokolowski 1999.

\begin{tabular}{|c|c|c|c|c|}
\hline $\begin{array}{l}\text { Population } \\
\text { Code }\end{array}$ & $\begin{array}{l}\text { Depth } \\
\text { (m) }\end{array}$ & $\begin{array}{l}\text { Salinity } \\
\text { (PSU) }\end{array}$ & $\begin{array}{c}\text { Temperature } \\
\left({ }^{\circ} \mathrm{C}\right)\end{array}$ & Specific environmental features \\
\hline SW60 & 60 & 9.6 & 5.1 & $\begin{array}{l}\text { Anoxia, hydrogen sulphide contamination, } \\
\text { metallic pollutant release from sediments }\end{array}$ \\
\hline SW40 & 40 & 8.2 & 13 & Thermo-halocline \\
\hline SW30 & 30 & 7.6 & 14.2 & Intermediate zone \\
\hline SW20 & 20 & 7.3 & 14.2 & Vistula inflow \\
\hline SW10 & 10 & 6.7 & 14.1 & Vistula inflow \\
\hline SW5 & 5 & 6.7 & 14.4 & Vistula inflow \\
\hline
\end{tabular}


3 Table 2: Nuclear diversity for each sample site. $\mathrm{N}_{\text {nuc }}$ : number of individuals analyzed for

4 microsatellite markers; $\mathrm{N}_{\text {all }}$ : allele number; $\mathrm{R}_{\text {all }}$ : allelic richness; $\mathrm{H}_{\mathrm{o}}$ : observed heterozygoty;

$5 \quad \mathrm{H}_{\mathrm{s}}$ : gene diversity; $F_{\text {IS }}$ : heterozygote deficiency. $\mathrm{N}_{\text {mito }}$ corresponds to the number of 6 individuals for which a mitochondrial sequence was obtained. See also Table S1.

\begin{tabular}{|c|c|c|c|c|c|c|c|}
\hline & $\mathbf{N}_{\text {nuc }}$ & $\mathbf{N}_{\text {mito }}$ & $\mathbf{N}_{\text {all }}$ & $\mathbf{R}_{\text {all }}$ & $\mathbf{H}_{\mathbf{0}}$ & $\mathbf{H}_{\mathbf{s}}$ & $\boldsymbol{F}_{\text {IS }}$ \\
\hline HEL85 & 8 & 5 & 4.33 & 1.58 & 0.405 & 0.511 & 0.328 \\
\hline HEL60 & 26 & 28 & 6.83 & 1.59 & 0.408 & 0.578 & 0.315 \\
\hline HEL45 & 17 & 29 & 6.16 & 1.62 & 0.394 & 0.591 & 0.373 \\
\hline GW40 & 11 & 24 & 4.33 & 1.51 & 0.313 & 0.493 & 0.417 \\
\hline SW5 & 18 & 19 & 5.14 & 1.56 & 0.282 & 0.534 & 0.539 \\
\hline SW10 & 18 & 20 & 5.83 & 1.60 & 0.461 & 0.586 & 0.255 \\
\hline SW20 & 23 & 21 & 5.83 & 1.58 & 0.370 & 0.565 & 0.373 \\
\hline SW30 & 10 & 25 & 3.83 & 1.58 & 0.535 & 0.519 & 0.049 \\
\hline SW40 & 5 & 23 & 2.5 & 1.53 & 0.447 & 0.440 & 0.183 \\
\hline SW60 & 8 & 18 & 4.16 & 1.55 & 0.317 & 0.520 & 0.464 \\
\hline Total & 165 & 232 & 11.16 & 1.61 & 0.281 & 0.600 & 0.558 \\
\hline Mean & 15.45 & 21.09 & 5.07 & 1.57 & 0.394 & 0.538 & 0.334 \\
\hline (S.D.) & 7.59 & 6.42 & 1.36 & 0.03 & 0.073 & 0.048 & 0.135 \\
\hline
\end{tabular}

